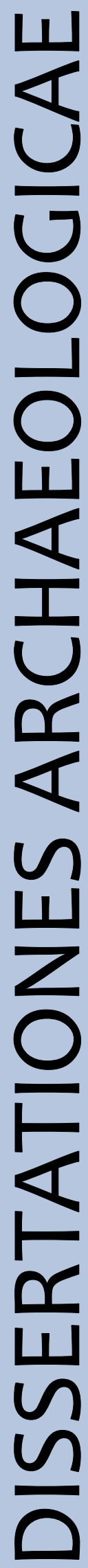

ex Instituto Archaeologico Universitatis de Rolando Eötvös nominatae
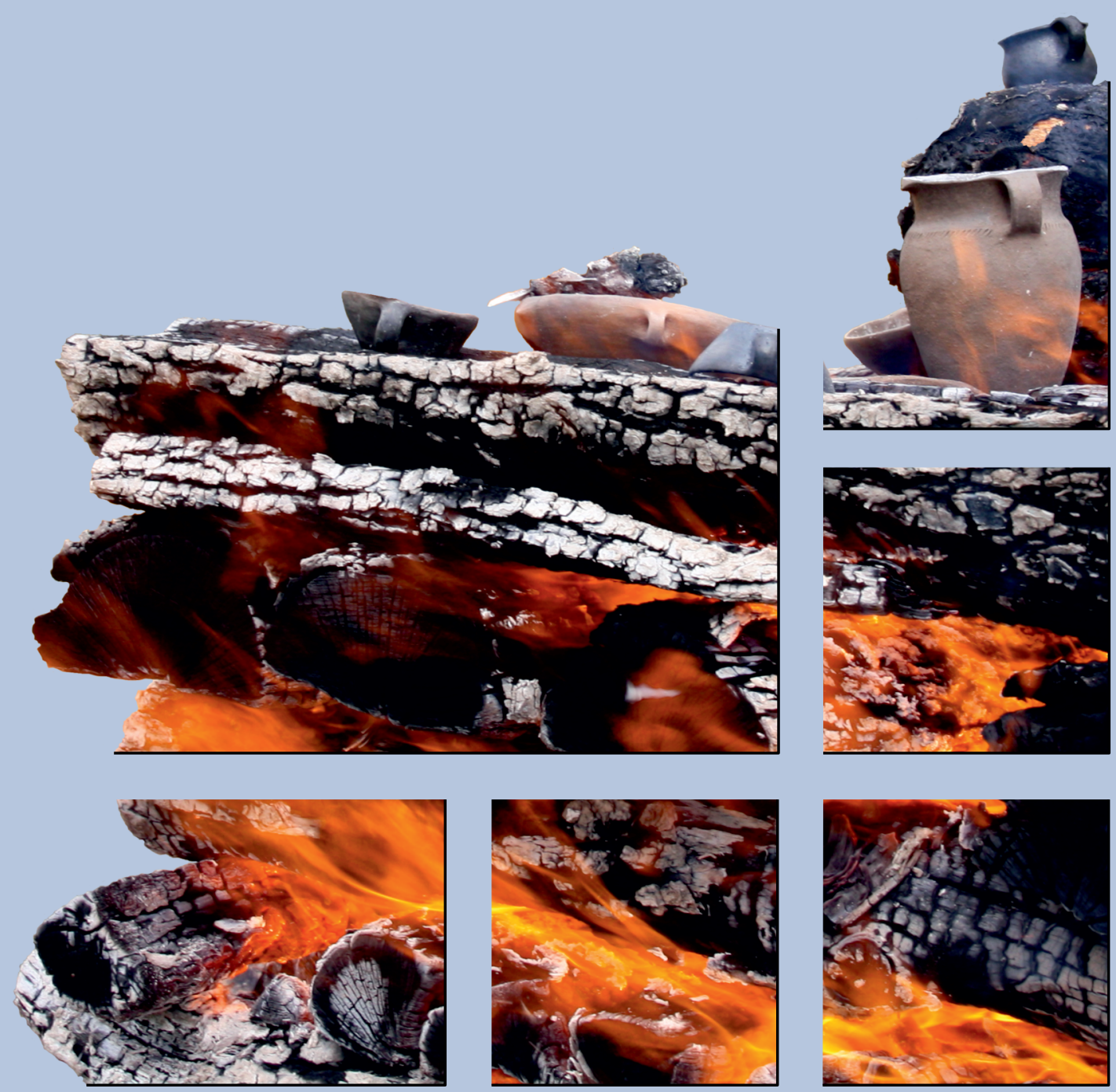

$$
\text { Ser。 3. No } 0_{0} \sigma_{0} \mid 2018
$$




\section{Dissertationes Archaeologicae ex Instituto Archaeologico}

Universitatis de Rolando Eötvös nominatae Ser. 3. No. 6.

Budapest 2018 


\section{Dissertationes Archaeologicae ex Instituto Archaeologico}

Universitatis de Rolando Eötvös nominatae Ser. 3. No. 6.

Editor-in-chief:

DÁvid BARTUS

Editorial board:

LÁsZló BARTOSIEWICZ

LÁSZLÓ BORHY

ZOLTÁN CZAJLIK

ISTVÁN FELD

GÁBOR KALLA

PÁL RACZKY

MiKLÓS SZABÓ

Tivadar Vida

Technical editor:

GÁBOR VÁcZI

Proofreading:

ZsófIA KondÉ

SzILVIA BARTUS-SzÖLLősI

Aviable online at http://dissarch.elte.hu

Contact: dissarch@btk.elte.hu

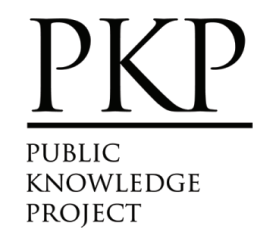

๑ E Eötvös Loránd University, Institute of Archaeological Sciences

Layout and cover design: Gábor Váczi

Budapest 2018 


\section{CONTENTS}

Zsolt Mester

In memoriam facques Tixier (1925-2018)

\section{ARTICLES}

Katalin SEBőK

On the possibilities of interpreting Neolithic pottery - Az újkökori kerámia értelmezési lehetőségeiről

András FüZESI - Pál RACZKY

Öcsöd-Kováshalom. Potscape of a Late Neolithic site in the Tisza region

Katalin SEBőK - Norbert FARAgó

Theory into practice: basic connections and stylistic affiliations of the Late Neolithic settlement at Pusztataskony-Ledence 1

Eszter Solnay

Early Copper Age Graves from Polgár-Nagy-Kasziba

László GuCsi - Nóra Szabó

Examination and possible interpretations of a Middle Bronze Age structured deposition

Kristóf FÜLÖP

Why is it so rare and random to find pyre sites? Two cremation experiments to understand the characteristics of pyre sites and their investigational possibilities

Gábor János TARBAY

"Looted Warriors" from Eastern Europe

Péter MogYoRós

Pre-Scythian burial in Tiszakürt

Szilvia JoHÁczi

A New Method in the Attribution? Attempts of the Employment of Geometric Morphometrics in the Attribution of Late Archaic Attic Lekythoi 
The Roman aqueduct of Brigetio

Lajos JuHÁsz

A republican plated denarius from Aquincum

Barbara HAJDU

Terra sigillata from the territory of the civil town of Brigetio

Krisztina HoppÁL - István VIDA - Shinatria AdHityatAma - Lu Yahui 461

'All that glitters is not Roman'. Roman coins discovered in East Java, Indonesia.

A study on new data with an overview on other coins discovered beyond India

\section{FIELD REPORTS}

Zsolt MESTER - Ferenc CSERPÁK - Norbert FARAGÓ

Preliminary report on the excavation at Andornaktálya-Marinka in 2018

Kristóf FÜLÖP - Denisa M. LÖNHARDT - Nóra SZABÓ - Gábor VÁcZI

Preliminary report on the excavation of the site Tiszakürt-Zsilke-tanya

Bence Simon - Szilvia JohÁcZI - Zita KIS

Short report on a rescue excavation of a prehistoric and Árpádian Age site near Tura

(Pest County, Hungary)

Zoltán CzAJlik - Katalin NovinszKi-Groma - László RupNIK - András BöDőcs - et al. 527

Archaeological investigations on the Süttö plateau in 2018

Dávid BARTus - László BORHY - Szilvia JoHÁczi - Emese SzÁMADó

Short report on the excavations in the legionary fortress of Brigetio (2017-2018)

Bence Simon - Szilvia JoháczI

Short report on the rescue excavations in the Roman Age Barbaricum near Abony

(Pest County, Hungary)

Szabolcs Balázs NAGY

Recent excavations at the medieval castle of Bánd 


\section{Thesis Abstracts}

Rita JENEY

Lost Collection from a Lost River: Interpreting Sir Aurel Stein's "Sarasvatī Tour" in the History of South Asian Archaeology

István VIDA

The Chronology of the Marcomannic-Sarmatian wars. The Danubian wars of Marcus Aurelius in the light of numismatics

Zsófia MASEK

Settlement History of the Middle Tisza Region in the $4^{\text {th }}-6^{\text {th }}$ centuries AD.

According to the Evaluation of the Material from Rákóczifalva-Bagi-földek 5-8-8A sites

Alpár Doвоs

Transformations of the human communities in the eastern part of the Carpathian Basin between the middle of the $5^{\text {th }}$ and $7^{\text {th }}$ century. Row-grave cemeteries in Transylvania, Partium and Banat 


\title{
The Chronology of the Marcomannic-Sarmatian wars
}

\section{The Danubian wars of Marcus Aurelius in the light of numismatics}

\author{
VIDA IsTVÁN \\ Hungarian National Museum \\ vida.istvan@hnm.hu
}

\begin{abstract}
Abstract of PhD thesis submitted in 2018 to the Archaeology Doctoral Programme, Doctoral School of History, Eötvös Loránd University, Budapest under the supervision of László Borhy.
\end{abstract}

I have chosen the title of my dissertation after a long contemplation. The appellation of the war is very diverse already on the ancient sources and epigraphic monuments. The different appellations were collected thoroughly by P. Kovács. ${ }^{1}$ My decision of using the term Marcomannic-Sarmatian wars was motivated by numismatic reasons and by the traditions of the research. After the great Roman victories during the first phase of the war the coinage mentions the Germanic people and the Sarmatians. So the term Germanic-Sarmatian war could have been the most proper phrase. On the other hand, the term Marcomannic wars is so widely spread in the research that creating a new one would have been very confusing. Thus instead of the Germanic adnominal I have used a reference to one of the most significant enemies. However, I also felt the use of the adnominal Sarmatian significant, because the defeat of the Sarmatians was also part of the propaganda expressed on coins, even if less expressively then that of the Germans. Therefore, I considered it important to use it in this work written from a numismatic point of view.

\section{Subject and goals}

The history of Marcus Aurelius' wars against various Germanic tribes and the Sarmatians is a well written up historical field from the point of view of the ancient written sources and epigraphy. Based on these sources the history of the era had been reconstructed in details, but there are still blank spots and open questions. For further proceeding the research and interpretation of new sources was necessary. One of these potential sources is numismatics. Although researchers already used some of its results earlier, an overall, detailed numismatic summary has not been done yet; nevertheless, numismatic evidences are the only ones that are absolutely contemporaneous with the events.

From a numismatic point of view, there are two possible ways of approach: the analysis of the coinage of the era, thus the presentation of the events of the war on the coins, or regarding the impact of the war on coinage. This historical source has to be dealt with circumspectly, as coins do not tell us the reality and the whole truth, but what the government propaganda wanted the people to know in the way it wanted them to know: the successes might be exaggerated, while the defeats are not mentioned. However, one might draw conclusions from silence and concealment, too.

1 KovÁcs 2005. 
The other way of approach is gathering and analysing coin hoards buried during the Marcomannic-Sarmatian wars. Their interpretation allows us to draw further inferences about the events of the war.

I must emphasize that I have only taken strictly numismatic evidences into account. I have interpreted the data obtained from them, but I did not try to assign their burial to certain events at any rate, or to confirm or deny the occurrence of historical events mentioned by written sources or epigraphic monuments.

\section{Structure and methods}

In the dissertation I worked with two scientific sources, thus it is composed of two separate, large parts. In the first one, I analysed the presentation of the war and related events in the successive issues of contemporary Roman coinage, and their impact on coinage. I studied the coinage from A.D. 167 to 181, as reference to the war can be found on coins of this period. Mostly, I only took numismatic evidences into account, and other sources were used only if they were needed to interpret the message of the coins.

I analysed coinage by emissions, in the smallest possible divisions to get the most accurate and detailed chronology of the events. I used the frame created by W. Szaivert for this, ${ }^{2}$ however, in some reasonable cases, I reclassified certain coins into other emissions, and respectively I integrated coins that had become known since his publication.

The photos of the discussed coins - or coins with the same design, if photos of the actual coins were not available - are appended to each emission.

In the second large part of the dissertation I studied the coin hoards in relation, or thought to be in relation with the Marcomannic-Sarmatian war. I did not create a separate catalogue, because their analysis is an integral part of the work. It can only be decided with the help of this analysis whether a hoard is indeed in relation with the war, and whether there is enough information from the hoard to use it for the dating of an event. Thus a separate catalogue would have resulted in large overlapping and many repetitions.

Although I based my dissertation primarily on the published archaeological material, I also made archival research. In addition, thanks to Hungarian and foreign researchers sharing information with me, some new, unpublished finds are incorporated as well.

I reidentified the published or unpublished but described hoards with the help of obsolete catalogues. The new identifications based on more modern catalogues and publications are described in the appendix of the dissertation. The new descriptions have usually modified the internal structure of the hoards, and in some cases, their dating has also changed or narrowed.

During the study and the analysis of the hoards I used information provided by the coins and - if they were known - the circumstances of the finds. During the several decades of the research of the Marcomannic wars, there had been so many uncertain theories and conclusions based on each other that it would have been impossible to work, agree or disagree with all of them one by one.

2 Szaivert 1986. He created a clear, exact, and detailed chronology for the dating of the coins of the period generally accepted by numismatists. 
For an easier overview I grouped the coin hoards found within the former borders of the empire by provinces, while the hoards found in the Barbaricum were divided into geographical groups: hoards found west of the Carpathian Basin, hoards of the Carpathian Basin, and hoards found east of the Carpathian Basin.

The maps of the findspots of the coin hoards are in the appendix of the dissertation, where I marked them by the division mentioned above. As there is no separate catalogue in the dissertation I gave the basic scientific data of the hoards (findspot - material - original/known number of coins - closure - type of burial - other objects in the hoards) in tables attached to each map.

The maps of the findspots are followed by diagrams. If it was necessary and I had enough data, I rearranged the distribution of the hoards by rulers, and I assigned the coins to actual issuers. This also meant simplification, as the coins minted to the members of the imperial family were assigned to the emperors. For a chronological distribution I always used the same diagrams; although seemingly there are many unnecessary, empty columns, this enables us to make easy and apparent comparisons.

The reidentified coin hoards are at the end of the appendix. I reidentified many coin hoards during my research. However, here I only included the ones that were either unpublished, or a reidentification with more modern catalogues was necessary for the study of their structure or for the determination of their closure.

\section{Results of the dissertation}

I was able to prove that many of the hoards previously related to the Marcomannic wars had not been or had not necessarily been hidden in the period, and thus cannot be used for dating the events.

Many authors mention anxiety, the weakening of collective security in Pannonia before the Marcomannic-Sarmatian wars, during the reign of Antoninus Pius, which is also supported by coin hoards: Poetovio (closure: 152) - there were only 11 coins in the hoard; Zalahosszúfalu (closure: 153) - by taking the counterfeit coins into account after 159, but both hoards are incomplete; Bonyhád (closure: 154) - 158 in fact; Szemely (closure: 158) - 161 to 176 in fact; Bara Osatina (closure: 160) - a very fragmentary hoard, and even more than half of the known coins are unidentifiable. Thus the premonitory signs of the Marcomannic-Sarmatian wars cannot be attested numismatically.

Another example can be the hoard horizon of 168-169, also mentioned in several publications. It is true in the case of the Gummern, Carnuntum, and Katafa hoards, but there were modern forgeries in the Witzelberg 'hoard', the closure of the Mocsolád hoard is 164, and the closure of the Baranyavár hoard is 165 . Because of the small number of the coins in the Katafa hoard (18 aurei), and the problems of the accumulation of gold coins, its deposition could happen many years later.

Besides excluding several hoards from the research, I could involve some new coin finds, such as the hoards of Szigetcsép and a new one from Brigetio.

Coin hoards of Pannonia Inferior and Moesia Inferior suggest that the Marcomannic-Sarmatian wars began one and a half years earlier than the conventional date. 
The invasion of Italy is not discernible with coin hoards, only the destruction of Opitergium/ Oderzo is marked by a hoard, and the coin find of Verona is the only known hoard that might have been buried in connection with the war in Northern Italy. The absence of the coin finds suggests that the shock caused by the enemy appearing in Italy was much greater than the actual devastation.

The Costobocian invasion of 170 cannot be attested with numismatic evidences, there is not any coin hoard known from Moesia Inferior or Thrace that could be dated for this time with certainty. This might be explained by the fact that most of the hoards were buried during the early years of the war; either because the population was unprepared and was taken by surprise, or the Barbarians were gradually expelled from the territory of the empire.

The analysis of the coin hoards found in the Barbaricum is much more problematic than that of the ones found in the Roman Empire. There was no active, everyday monetary circulation in the territory. As there was no regular monetary supply, the closure of the hoards is dating the period the coins were taken or exported from the empire, and usually do not indicate the time of their burials.

Even though I have collected and analysed the coin hoards of the Barbaricum thoroughly, it seems that at the present stage of research it is not possible to date the events of the war with their help. The concentration of the finds in certain territories cannot be explained unequivocally: it might be caused by the uneven scientific research, or might indicate where the people attacking the empire came from, or they might mark the direction of the Roman counter attacks.

\section{The chronology of the Marcomannic-Sarmatian war based on coinage and coin hoards}

165

According to the coin hoards the Barbarians attack Moesia Inferior and Pannonia Inferior. The invasion in Pannonia might reach the central parts of Pannonia Superior as well.

166

Based on the Sotin hoard there is an attack against the southern parts of Pannonia Inferior. A probable attack against Raetia.

167

The coin hoards bear evidence of Barbarian attacks along the whole Danubian limes: Raetia (or probably already in the previous year), Noricum, Pannonia Superior, Dacia, and Moesia Inferior. The coinage informs on the beginning of Marcus Aurelius' and Lucius Verus' joint campaign. The two emperors divide the tasks: Marcus Aurelius is the strategist, while Lucius Verus is the actual commander of the troops.

168

Early in the year, in the beginning of the campaign the Romans are successful. The army led by Lucius Verus is victorious. Later in the year the attack burns out, there is no decisive victory. Coin hoards give evidence of invasion of Moesia Superior. By the end of the year the Roman campaign is a total failure, they might also be defeated. The beginning of Marcus Aurelius' illness. 
169

Early in the year the emperors head for Rome. Death of Lucius Verus. Marcus Aurelius stays in Rome in the middle of the year. According to the Carnuntum 3 hoard, Pannonia is attacked. The earliest possible date for the invasion of Italy based on the coin hoards of Gummern and Oderzo. Late this year Marcus Aurelius departs Rome for a new campaign against the Barbarians.

170

The actual military actions start early in this year. The Romans achieve initial successes, they might overvalue their victories and expect a prompt completion of the campaign. However, in spring they suffer a catastrophic defeat. In the rest of the year the Romans are helpless with the Barbarians.

171

The Romans are helpless against the Barbarians, the absence of Roman victories leads to unrest within the army in spring. In autumn a decisive victory is won over the Germans, the expelling of the enemy from the territory of the empire begins. Late in the year preparations for a new campaign begin.

172

The Roman army led by Marcus Aurelius crosses the Danube River, the theatre of war is no longer in Roman territory, but in Germanic land. A possible date of the lightning miracle. At the end of the year, Marcus Aurelius returns to Rome.

173

The war continues against the Sarmatians, the coinage gives no details.

174

The war continues further, the details are not known. The lack of success might be the reason of the unrest within the army in the second half of the year.

175

In spring, the campaign continued in spite of the revolt of Avidius Cassius brought Roman victory over the Sarmatians. The end of the first phase of the war.

176

Late in the year, the triumph of Marcus Aurelius and Commodus in Rome.

177

The war is renewed, the Barbarians attack Pannonia and Dacia. The two emperors - just like Marcus Aurelius and Lucius Verus in 167 - divide the tasks. Commodus is the immediate commander of the troops. The first victory is followed by a serious defeat.

178

The war continues. Dacia is invaded again, the coinage does not provide information about the events, most likely due to the absence of Roman victories. This might lead to the unrest within the army in autumn.

179

In spring the Romans achieve victory. The war continues, but coins do not refer to any particular event.

180

Early in the year Marcus Aurelius dies before the war is over. Commodus returns to Rome, end of the fights. Late in the year Commodus' triumph at Rome. 


\section{References}

KovÁcs P. 2005: Marcus Aurelius esőcsodája és a markomann háborúk. Pécs.

SzAivert, W. 1986: Die Münzprägung der Kaiser Marcus Aurelius, Lucius Verus und Commodus (161192). Wien. 